Commentary

\title{
As predicted by hyperfunction theory, rapamycin treatment during development extends lifespan
}

\author{
Mikhail V. Blagosklonny ${ }^{1}$ \\ ${ }^{1}$ Roswell Park Comprehensive Cancer Center, Buffalo, NY 14263, USA
}

Correspondence to: Mikhail V. Blagosklonny; email: Blagosklonny@oncotarget.com, Blagosklonny@rapalogs.com

Keywords: quasi-programmed aging, mTOR, sirolimus, growth, reprogramming

Received: March 2, 2022 Accepted: March 5, 2022 Published: March 5, 2022

Copyright: (c) 2022 Blagosklonny. This is an open-access article distributed under the terms of the Creative Commons Attribution License (CC BY 3.0), which permits unrestricted use, distribution, and reproduction in any medium, provided the original author and source are credited.

As suggested in 2006, by slowing down the mTORdriven developmental program, rapamycin must slow down quasi-programmed aging [1]. In other words, targeting development with rapamycin must lead to a longer lifespan. An elegant study by Gladyshev and coworkers has confirmed this prediction [2].

According to hyper-function theory, aging is a quasiprogram, a purposeless continuation of the growth program that has not been switched off upon its completion [1]. Aging is not programmed, only development is. Unlike a program, a quasi-program has no aim, although, like a program, it can be modulated $[1,3,4]$. For example, excessive nutrients and calorie restriction can accelerate and decelerate aging, respectively.

Aging is driven by hyperfunctional signal-transduction pathways which, via cellular and systemic hyperfunctions, cause age-related diseases, whose sum is called aging [1]. Hyperfunctions cause organ damage (not molecular damage), resulting in loss of functions and secondary functional decline $[1,5]$.

The nutrient-sensing mTOR pathway promotes cellular growth [6-8] and cellular senescence, which is a continuation of cellular growth, when the cell cycle is blocked $[9,10]$. According to hyperfunction theory, age-related diseases are quasi-programmed $[1,11]$ with clear-cut examples in simple organisms such as $C$. elegans [11-15]. Hyperfunction theory was extensively reviewed $[1,5,11,16$-20]. Critical comments [2123] have been addressed [5, 24]. Importantly, hyperfunction theory is mTOR-centric, describing mTOR-driven aging and its diseases [1]. By slowing down aging, rapamycin delays age-related diseases $[1$, $25,26]$.

To maximally extend health and lifespan in humans, it was suggested that the treatment with rapamycin should be started at a young age: "As an anti-aging drug, rapamycin will prevent diseases rather than cure complications of diseases. Rapamycin will prevent [organ] damage but not to reverse damage. It might prevent diabetes and obesity but not diabetic gangrene and stroke. It might prevent macular degeneration but will unlikely cure blindness. Rapamycin will not repair broken bones but might prevent osteoporosis... rapamycin will be most useful as [an] anti-aging drug to slow down senescence and to prevent diseases" [1].

It was suggested in 2006 to take rapamycin immediately to the clinic to suppress human aging [1], even though longevity studies in animals were not yet performed. Starting from 2009, numerous studies demonstrated that rapamycin extends lifespan in mice [27-39].

Hyperfunction theory predicts that rapamycin can slow down aging by two complementary mechanisms:

(a) directly suppressing the quasi-program of aging

b) reprogramming aging by slowing the developmental-growth program 
To demonstrate reprogramming, rapamycin should be given for a brief period during development.

Shindyapina et al. showed that treatment with rapamycin for the first 45 days of life extends median lifespan by $10 \%$ [2]. Health was improved as measured by gait speed, frailty index, and glucose and insulin tolerance tests [2]. Rapamycin-treated mice were small and did not catch up on growth later [2].

The hyperfunction theory explains why a large-body correlates with longevity between species (for example, elephants live longer than mice, which live longer than flies), but in contrast, within each species, it is a small body size that is associated with longevity [40]. Lifelong small body size after a brief treatment is consistent with reprogramming of the growth program.

Notably, life extension by rapamycin was mostly observed in male mice [2]. This is consistent with the finding that mTOR is overactivated in young male mice compared with young female mice, thus explaining robustness of males at young age and their shorter lifespan [41].

Supporting the notion of rapamycin-induced reprogramming, previous studies found that (a) even transient treatment with rapamycin can extend lifespan $[27,36,39]$ (b) a single rapamycin injection can lower body weight set point in the long run [42] and (c) rapamycin can affect the mTOR pathway activity long term by preventing obesity $[43,44]$.

\section{Further suggestions}

To further study rapamycin-induced reprogramming of aging, pregnant mice should be treated with a single subcutaneous injection of rapamycin and the lifespan of their offspring should be measured. Prenatal (before birth) rapamycin treatment on early postnatal development has been studied [45-47]. For example, prenatally rapamycin-treated neonates are small, and body weight and left ventricular mass remain reduced in adulthood [47]. However, lifespan was not measured. (Note: rapamycin pre-treatment increased mortality immediately after the birth [47] because mTOR is essential early in life. Early-life death is not agingdriven and should be excluded from the age-related mortality curve).

At what age may rapamycin treatment be started in order to maximally extend human lifespan? Based on murine data, treatment with rapamycin can be started at a very old age. Still, in theory, the maximal effect potentially may be achieved before age-related diseases and pre-diseases become apparent in humans [1].
However, it should not be started too early because mTOR is essential for growth and early life fitness. In my opinion, rapamycin treatment (for anti-aging purposes) may only be started when a young adult can make informed decisions and should not be allowed before the age of 21. Doctors should consider that rapamycin may negatively affect reproduction, albeit reversibly. I believe that the initial dose should be very low and gradually increase with older age, when full individual doses are achieved. An anti-aging dose/ schedule is a maximum dose that do not yet cause side effects in a particular person [48]. Self-treatment is unacceptable and doses are highly individual $[48,49]$.

\section{Disclaimer}

This commentary is for information purposes, not medical advice.

\section{CONFLICTS OF INTEREST}

The author declares no conflicts of interest.

\section{REFERENCES}

1. Blagosklonny MV. Aging and immortality: quasiprogrammed senescence and its pharmacologic inhibition. Cell Cycle. 2006; 5:2087-102. https://doi.org/10.4161/cc.5.18.3288 PMID:17012837

2. Shindyapina AV, Cho Y, Kaya A, Tyshkovskiy A, Castro JP, Gordevicius J, et al. Rapamycin treatment during development extends lifespan and healthspan. bioRxiv. 2022:2022.02.18.481092. https://doi.org/10.1101/2022.02.18.481092

3. Blagosklonny MV. Revisiting the antagonistic pleiotropy theory of aging: TOR-driven program and quasi-program. Cell Cycle. 2010; 9:3151-56. https://doi.org/10.4161/cc.9.16.13120 PMID:20724817

4. Blagosklonny MV. Aging is not programmed: genetic pseudo-program is a shadow of developmental growth. Cell Cycle. 2013; 12:3736-42. https://doi.org/10.4161/cc.27188 PMID:24240128

5. Blagosklonny MV. Answering the ultimate question "what is the proximal cause of aging?". Aging (Albany NY). 2012; 4:861-77. https://doi.org/10.18632/aging.100525 PMID:23425777

6. Wullschleger $S$, Loewith $R$, Hall MN. TOR signaling in growth and metabolism. Cell. 2006; 124:471-84. https://doi.org/10.1016/i.cell.2006.01.016 PMID:16469695 
7. Saxton RA, Sabatini DM. mTOR Signaling in Growth, Metabolism, and Disease. Cell. 2017; 168:960-76. https://doi.org/10.1016/j.cell.2017.02.004 PMID:28283069

8. Kim J, Guan KL. mTOR as a central hub of nutrient signalling and cell growth. Nat Cell Biol. 2019; 21:6371. $\quad$ https://doi.org/10.1038/s41556-018-0205-1 PMID: 30602761

9. Demidenko ZN, Blagosklonny MV. Growth stimulation leads to cellular senescence when the cell cycle is blocked. Cell Cycle. 2008; 7:3355-61. https://doi.org/10.4161/cc.7.21.6919 PMID:18948731

10. Demidenko ZN, Zubova SG, Bukreeva EI, Pospelov VA, Pospelova TV, Blagosklonny MV. Rapamycin decelerates cellular senescence. Cell Cycle. 2009; 8:1888-95. https://doi.org/10.4161/cc.8.12.8606 PMID:19471117

11. Gems D. The aging-disease false dichotomy: understanding senescence as pathology. Front Genet. 2015; 6:212.

https://doi.org/10.3389/fgene.2015.00212

PMID:26136770

12. de la Guardia Y, Gilliat AF, Hellberg J, Rennert P, Cabreiro F, Gems D. Run-on of germline apoptosis promotes gonad senescence in C. elegans. Oncotarget. 2016; 7:39082-96.

https://doi.org/10.18632/oncotarget.9681 PMID:27256978

13. Ezcurra M, Benedetto A, Sornda T, Gilliat AF, Au C, Zhang $Q$, et al. C. elegans Eats Its Own Intestine to Make Yolk Leading to Multiple Senescent Pathologies. Curr Biol. 2018; 28:2544-2556.e5. https://doi.org/10.1016/j.cub.2018.06.035 PMID:30100339

14. Wang $H$, Zhang $Z$, Gems D. Monsters in the uterus: teratoma-like tumors in senescent $C$. elegans result from a parthenogenetic quasi-program. Aging (Albany NY). 2018; 10:1188-89.

https://doi.org/10.18632/aging.101486

PMID:29923830

15. Wang $H$, Zhao $Y$, Ezcurra $M$, Benedetto $A$, Gilliat $A F$, Hellberg $J$, et al. A parthenogenetic quasi-program causes teratoma-like tumors during aging in wild-type C. elegans. NPJ Aging Mech Dis. 2018; 4:6. https://doi.org/10.1038/s41514-018-0025-3 PMID:29928508

16. Blagosklonny MV. Rapamycin and quasi-programmed aging: four years later. Cell Cycle. 2010; 9:1859-62. https://doi.org/10.4161/cc.9.10.11872 PMID:20436272
17. Blagosklonny MV. The hyperfunction theory of aging: three common misconceptions. Oncoscience. 2021; 8:103-07. https://doi.org/10.18632/oncoscience.545 PMID: $\underline{34549076}$

18. Gems D, de la Guardia Y. Alternative Perspectives on Aging in Caenorhabditis elegans: Reactive Oxygen Species or Hyperfunction? Antioxid Redox Signal. 2013; 19:321-29.

https://doi.org/10.1089/ars.2012.4840

PMID:22870907

19. Gems D, Partridge L. Genetics of longevity in model organisms: debates and paradigm shifts. Annu Rev Physiol. 2013; 75:621-44.

https://doi.org/10.1146/annurev-physiol-030212183712 PMID:23190075

20. Gems D. The hyperfunction theory: an emerging paradigm for the biology of aging. Ageing Res Rev. 2022; 74:101557.

https://doi.org/10.1016/j.arr.2021.101557 PMID:34990845

21. Zimniak P. What is the Proximal Cause of Aging? Front Genet. 2012; 3:189.

https://doi.org/10.3389/fgene.2012.00189 PMID:23056007

22. Gladyshev VN. Aging: progressive decline in fitness due to the rising deleteriome adjusted by genetic, environmental, and stochastic processes. Aging Cell. 2016; 15:594-602.

https://doi.org/10.1111/acel.12480

PMID:27060562

23. de Grey AD. Programs, Hyperfunction, and Damage: Why Definitions and Logic Matter So Much in Biogerontology. Rejuvenation Res. 2021; 24:83-85. https://doi.org/10.1089/rej.2021.0015 PMID: 33784821

24. Blagosklonny MV. Response to the Thought-Provoking Critique of Hyperfunction Theory by Aubrey de Grey. Rejuvenation Res. 2021; 24:170-72. https://doi.org/10.1089/rej.2021.0018 PMID: $\underline{3784825}$

25. Blagosklonny MV. Prospective treatment of agerelated diseases by slowing down aging. Am J Pathol. 2012; 181:1142-46. https://doi.org/10.1016/j.ajpath.2012.06.024 PMID:22841821

26. Kaeberlein M. Longevity and aging. F1000Prime Rep. 2013; 5:5. https://doi.org/10.12703/P5-5 PMID:23513177

27. Chen $C$, Liu Y, Liu Y, Zheng P. mTOR regulation and therapeutic rejuvenation of aging hematopoietic stem cells. Sci Signal. 2009; 2:ra75. 
https://doi.org/10.1126/scisignal.2000559

PMID:19934433

28. Harrison DE, Strong R, Sharp ZD, Nelson JF, Astle CM, Flurkey $\mathrm{K}$, et al. Rapamycin fed late in life extends lifespan in genetically heterogeneous mice. Nature. 2009; 460:392-95.

https://doi.org/10.1038/nature08221

PMID: 19587680

29. Anisimov VN, Zabezhinski MA, Popovich IG, Piskunova TS, Semenchenko AV, Tyndyk ML, et al. Rapamycin extends maximal lifespan in cancer-prone mice. Am J Pathol. 2010; 176:2092-97.

https://doi.org/10.2353/ajpath.2010.091050

PMID:20363920

30. Anisimov VN, Zabezhinski MA, Popovich IG, Piskunova $T S$, Semenchenko AV, Tyndyk ML, Y, et al. Rapamycin increases lifespan and inhibits spontaneous tumorigenesis in inbred female mice. Cell Cycle. 2011; 10:4230-36.

https://doi.org/10.4161/cc.10.24.18486

PMID:22107964

31. Miller RA, Harrison DE, Astle CM, Baur JA, Boyd AR, de Cabo $R$, et al. Rapamycin, but not resveratrol or simvastatin, extends life span of genetically heterogeneous mice. J Gerontol A Biol Sci Med Sci. 2011; 66:191-201.

https://doi.org/10.1093/gerona/glq178

PMID:20974732

32. Komarova EA, Antoch MP, Novototskaya LR, Chernova OB, Paszkiewicz G, Leontieva OV, Blagosklonny MV, Gudkov AV. Rapamycin extends lifespan and delays tumorigenesis in heterozygous p53+/- mice. Aging (Albany NY). 2012; 4:709-14. https://doi.org/10.18632/aging.100498

PMID:23123616

33. Miller RA, Harrison DE, Astle CM, Fernandez E, Flurkey K, Han M, et al. Rapamycin-mediated lifespan increase in mice is dose and sex dependent and metabolically distinct from dietary restriction. Aging Cell. 2014; 13:468-77.

https://doi.org/10.1111/acel.12194

PMID:24341993

34. Zhang Y, Bokov A, Gelfond J, Soto V, Ikeno Y, Hubbard $\mathrm{G}$, et al. Rapamycin extends life and health in C57BL/6 mice. J Gerontol A Biol Sci Med Sci. 2014; 69:119-30. https://doi.org/10.1093/gerona/glt056 PMID:23682161

35. Johnson SC, Yanos ME, Bitto A, Castanza A, Gagnidze A, Gonzalez B, et al. Dose-dependent effects of mTOR inhibition on weight and mitochondrial disease in mice. Front Genet. 2015; 6:247. https://doi.org/10.3389/fgene.2015.00247 PMID:26257774

36. Bitto A, Ito TK, Pineda VV, LeTexier NJ, Huang HZ, Sutlief $E$, et al. Transient rapamycin treatment can increase lifespan and healthspan in middle-aged mice. elife. 2016; 5:5.

https://doi.org/10.7554/eLife.16351 PMID:27549339

37. Khapre RV, Kondratova AA, Patel S, Dubrovsky $Y$, Wrobel M, Antoch MP, et al. BMAL1-dependent regulation of the mTOR signaling pathway delays aging. Aging (Albany NY). 2014; 6:48-57. https://doi.org/10.18632/aging.100633

PMID:24481314

38. Arriola Apelo SI, Pumper CP, Baar EL, Cummings NE, Lamming DW. Intermittent Administration of Rapamycin Extends the Life Span of Female C57BL/6J Mice. J Gerontol A Biol Sci Med Sci. 2016; 71:876-81. https://doi.org/10.1093/gerona/glw064 PMID:27091134

39. Strong R, Miller RA, Bogue M, Fernandez E, Javors $M A$, Libert $S$, et al. Rapamycin-mediated mouse lifespan extension: late-life dosage regimes with sexspecific effects. Aging Cell. 2020; 19:e13269. https://doi.org/10.1111/acel.13269 PMID:33145977

40. Blagosklonny MV. Big mice die young but large animals live longer. Aging (Albany NY). 2013; 5:227-33. https://doi.org/10.18632/aging.100551 PMID:23603822

41. Leontieva OV, Paszkiewicz GM, Blagosklonny MV. Mechanistic or mammalian target of rapamycin (mTOR) may determine robustness in young male mice at the cost of accelerated aging. Aging (Albany NY). 2012; 4:899-916.

https://doi.org/10.18632/aging.100528

PMID:23443503

42. Hebert $M$, Licursi $M$, Jensen $B$, Baker $A$, Milway $S$, Malsbury $C$, et al. Single rapamycin administration induces prolonged downward shift in defended body weight in rats. PLoS One. 2014; 9:e93691. https://doi.org/10.1371/journal.pone.0093691 PMID:24787262

43. Leontieva OV, Paszkiewicz GM, Blagosklonny MV. Comparison of rapamycin schedules in mice on highfat diet. Cell Cycle. 2014; 13:3350-56. https://doi.org/10.4161/15384101.2014.970491 PMID:25485580

44. Leontieva OV, Paszkiewicz GM, Blagosklonny MV. Weekly administration of rapamycin improves survival and biomarkers in obese male mice on highfat diet. Aging Cell. 2014; 13:616-22. https://doi.org/10.1111/acel.12211 PMID:24655348 
45. Anderl S, Freeland M, Kwiatkowski DJ, Goto J. Therapeutic value of prenatal rapamycin treatment in a mouse brain model of tuberous sclerosis complex. Hum Mol Genet. 2011; 20:4597-604.

https://doi.org/10.1093/hmg/ddr393

PMID:21890496

46. Urbano-Gámez JD, Casañas JJ, Benito I, Montesinos ML. Prenatal treatment with rapamycin restores enhanced hippocampal mGluR-LTD and mushroom spine size in a Down's syndrome mouse model. Mol Brain. 2021; 14:84. https://doi.org/10.1186/s13041021-00795-6 PMID:34034796

47. Hennig M, Fiedler S, Jux C, Thierfelder L, Drenckhahn JD. Prenatal Mechanistic Target of Rapamycin Complex 1 (m TORC1) Inhibition by Rapamycin Treatment of Pregnant Mice Causes Intrauterine Growth Restriction and Alters Postnatal Cardiac Growth, Morphology, and Function. J Am Heart Assoc. 2017; 6:e005506.

https://doi.org/10.1161/JAHA.117.005506

PMID:28778941

48. Blagosklonny MV. Rapamycin for longevity: opinion article. Aging (Albany NY). 2019; 11:8048-67. https://doi.org/10.18632/aging.102355

PMID:31586989

49. Johnson SC, Kaeberlein M. Rapamycin in aging and disease: maximizing efficacy while minimizing side effects. Oncotarget. 2016; 7:44876-78. https://doi.org/10.18632/oncotarget.10381 PMID:27384492 